\title{
REKAYASA ULANG SISTEM PENCAHAYAAN DAN PENGKONDISIAN UDARA PADA GEDUNG MAGISTER SAINS TERAPAN POLITEKNIK NEGERI BANDUNG
}

\author{
Achmad Renaldi, Dadan Purnama, Mei Sutrisno, Muchtar \\ Jurusan Teknik Sipil Politeknik Negeri B andung \\ Jl. Gegerkalong Hilir Ds.Ciwaruga Bandung 40012. E-mail: meisutrisno@polban.ac.id
}

\begin{abstract}
ABSTRAK
Optimalisasi penggunaan energi pada suatu gedung bertujuan untuk mengurangi pemakaian energi listrik berlebih, sehingga dapat menekan biaya operasional pada gedung tersebut. Salah satu ide optimalisasi yang dapat direncanakan adalah melakukan rekayasa ulang pada sistem pencahayaan dan pengkondisian udara.Hal ini coba diterapkan pada gedung magister sains terapan Politeknik Negeri Bandung. Evaluasi sistem pencahayaan pada bangunan eksisting dilakukan dengan mengukur nilai lux (tingkat cahaya) pada setiap ruangan. Sedangkan evaluasi sistem pengkondisian udara pada bangunan eksisting yang dilakukan adalah mengukur kecepatan angin, suhu udara luar dan dalam ruangan pada jam operasional gedung, serta kelembaban udara. Pengolahan data hasil evaluasi selanjutnya dijadikan acuan untuk menentukan jenis usulan desain baru yang akan direkomendasikan. Untuk sistem pencahayaan, usulan desain yang direkomendasikan adalah penambahan cerobong cahaya, pemasangan glassblock, penggantian warna cat dinding, serta penggantian jenis dan spesifikasi lampu. Sedangkan untuk pengkondisian udara, usulan yang direkomendasikan adalah desain cross ventilation menggunakan jendela fleksibel, penggunaan exhaust fan, serta pergantian jenis dan spesifikasi komponen pengkondisian udara yang lebih hemat energi. Dari rekayasa ulang yang telah direncanakan, selanjutnya dilakukan perhitungan biaya operasional untuk jangka waktu 20 tahun kedepan yang mencakup biaya penggunaan listrik, biaya perawatan, biaya penggantian asset, serta biaya investasi (RAB) dengan dipengaruhi oleh kenaikan tarif listrik rata-rata dan infasi pada setiap tahunnya. Berdasarkan hasil perhitungan, didapatkan nilai perbandingan penghematan biaya operasional hasil usulan desain dengan biaya operasional kondisi eksisting yaitu sebesar 286\% dengan nilai NPV hasil desain sebesar Rp. 5.609.940.958
\end{abstract}

Kata kunci: Evaluasi, Sistem Pencahayaan, Sistem Pengkondisian Udara, Rekayasa Ulang, Biaya Operasional.

\section{PENDAHULUAN}

Pada dasarnya, bangunan berperan penting dalam menunjang berbagai macam aktifitas dan juga sebagai pelindung dari segala faktor penyebab ketidaknyamanan seperti hujan, terik matahari,dan udara panas. Untuk merubah kondisi ketidaknyamanan tersebut seringkali membutuhkan alat penunjang kenyamanan dengan kualitas dan jumlah tertentu yang secara tidak langsung menyebabkan bangunan menggunakan energi listrik secara tidak efisien, contohnya pada penggunaan Air Conditioning (AC) dan sistem penerangan berdaya besar. Kedua hal tersebut dapat memberikan dampak negatif yang cukup signifikan terhadap efisiensi pemakaian energi listrik dan kemudian mempengaruhi penggunaan biaya operasional bangunan. Hal ini perlu diperhatikan terlebih untuk gedung yang akan difungsikan sebagai sarana pendidikan, dimana segala fasilitas penunjang pendidikan harus berada dalam keadaan yang baik, sehingga pada pengaplikasianya tidak mungkin menggunakan energi listrik yang kecil.
Tujuan

Tujuan penulisan penelitian in i adalah:

1. Melakukan analisis dan evaluasi sistem pencahayaan dan pengkondisian udara alami berdasarkan kondisi eksisting pada setiap ruangan Gedung Magister Sains Terapan.

2. Melakukan rekayasa ulang sebagai solusi optimalisasi sistem pencahayaan dan pengkondisian udara alami berdasarkan hasil evaluasi yang telah dilakukan.

3. Menghitung biaya operasional gedung hasil perencanaan ulang selama 20 tahun kedepan.

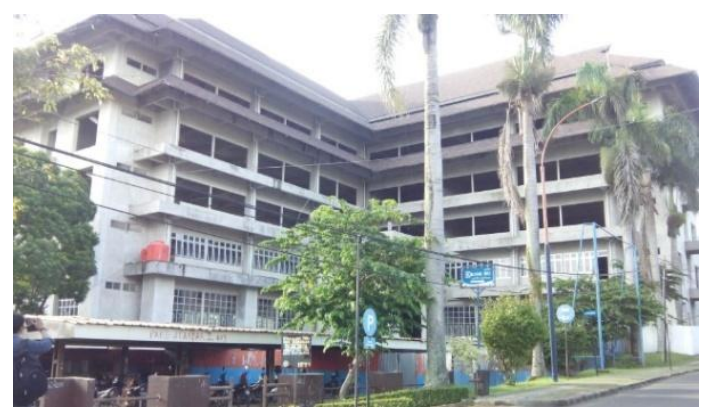

Gambar 1. Gedung MST Polban 


\section{METODOLOGI}

Metodologi penelitian yang dilakukan meliputi observasi, survei, studi literatur, dan analisis. Untuk lebih jelasnya, metodologi penelitian tersebut ditunjukkan pada Gambar 2 berikut:



Gambar 2. Diagram alir metodologi penelitian

Peralatan yang digunakan dala m observasi adalah:

- Digital Lux Meter (Alat pengukur lux ruangan).

- Temperature \& Humidity Alarm (Alat pengukur suhu dan kelembaban ruangan).

- Anemometer (A lat pengukur kecepatan udara).

\section{HAS IL DAN PEMBAHASAN}

\section{Kondisi Eksisting}

Gedung MST POLBAN memiliki jumlah 5 lantai tipikal dengan masing masing lantai memiliki ketinggian 4,20 meter kecuali lantai 1 yang mempunyai tinggi lantai mencapai 5,2 meter. Gedung ini terd iri dari ruangan expo, perpustakaan, ruang kelas, dan laboratorium. Gambar 3. merupakan salah satu denah yang terdapat pada Gedung MST.



Gambar 3. Denah Lantai Gedung MST

\section{Evaluasi Sistem Pencahayaan Alami}

Evaluasi sistem pencahayaan alami yang dilakukan adalah melakukan observasi lapangan menggunakan digital lux meter (Gambar 4) yang mengacu pada aturan SNI 7062-2004 tentang "Pengukuran Intensitas Pencahayaan Lux Meter”. Pengujian dilakukan pada jam operasional (pagi, siang, sore) dan mengacu pada aturan SNI 6197-2011 mengenai tingkat pencahayaan yang direkomendasikan pada suatu ruangan.

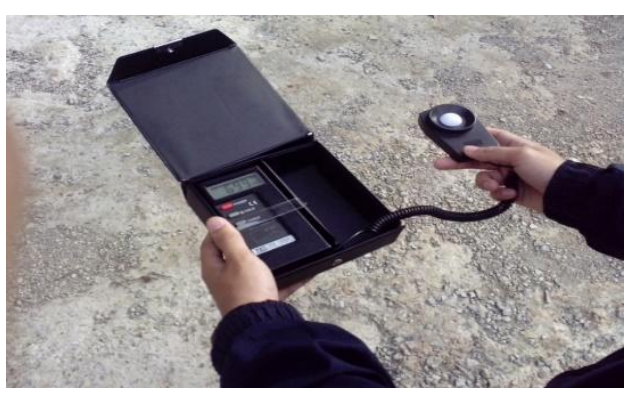

Gambar 4. Digital lux meter

Berdasarkan hasil observasi yang telah dilakukan, didapatkan rekap sebagai berikut:

- Pada beberapa ruangan, terdapat intensitas pencahayaan yang belum memenuhi standar.

- Intensitas pencahayaan tertinggi umumnya berada pada jam operasional siang hari.

- Intensitas pencahayaan terbesar berada pada TUU1 (2,5m dari bukaan terbesar).

\section{Evaluasi Sistem Pencahayaan B uatan}

Evaluasi terhadap sistem pencahayaan perlu dilakukan untuk mengetahui apakah perencanaan pencahayaan buatan (lampu) yang digunakan pada 
gedung tersebut telah memenuhi persyaratan. Informasi yang diperlukan dalam melakukan evaluasi adalah data luas ruangan dan jenis lampu yang digunakan (berdasarkan RKS).

Tabel 1. Standar Tingkat Lux setiap ruangan (SNI 6197-2011)

\begin{tabular}{|l|c|}
\hline \multicolumn{1}{|c|}{ Fungsi ruangan/area } & $\begin{array}{c}\text { Tingkat pencahayaan } \\
\text { (lux) }\end{array}$ \\
\hline Ruang resepsionis & 300 \\
\hline Ruang kerja & 350 \\
\hline Ruang rapat & 300 \\
\hline Gudang & 150 \\
\hline Ruang komputer & 350 \\
\hline Ruang staff & 350 \\
\hline Ruang teleconference & 300 \\
\hline Ruang kelas & 300 \\
\hline Perpustakaan & 500 \\
\hline Laboratorium & 500 \\
\hline Lobby & 500 \\
\hline Toilet & 250 \\
\hline
\end{tabular}

Perhitungan yang digunakan pada evaluasi sistem pencahayaan buatan adalah sebagai berikut:

- Perhitungan tingkat pencahayaan rata-rata

$$
E_{\text {rata }- \text { rata }}=\frac{F_{\text {total }} x k_{p} x k_{d}}{A}(\operatorname{lux})
$$

Keterangan:

$$
\begin{array}{ll}
\mathrm{F} \text { total } & =\text { Nilai flux (lu men) dari tipe la mpu } \\
\mathrm{Kp} & =\text { Koefisien penggunaan }(0,5-0,95) \\
\mathrm{Kd} & =\text { Koefisien penyusutan }(0,8)
\end{array}
$$

- Perhitungan daya listrik ruangan per 1 meter persegi

$$
\text { Daya Listrik }=\frac{\sum \text { Watt }(\text { Termasuk Balast })}{\text { luas }\left(m^{2}\right)}
$$

Keterangan:

Standar maksimal untuk daya listrik suatu ruangan adalah $15 \mathrm{w} / \mathrm{m}^{2}$

Berdasarkan perhitungan hasil evaluasi sistem pencahayaan buatan pada Gedung MST, didapatkan rekap sebagai berikut:

- Terdapat spesifikasi lampu yang tidak memenuhi standar pada ruangan tertentu. Salah satunya pada ruangan expo lantai 1 .

- Terdapat penggunaan lampu yang melebihi standar, dengan selisih rata-rata lux dan standar mencapai 50\%. Hal ini diindikasikan dapat menyebabkan pemboros an energi.

- Keseluruhan ruangan telah mencukupi standar daya listrik yang disarankan.

\section{Evaluasi Sistem Pengkondisian Udara Alami}

Evaluasi pengkondisian udara pada gedung MST dilakukan dengan melakukan observasi langsung di lapangan menggunakan alat Temperature \& Humidity Alarm dan Anemometer. Acuan yang digunakan dalam melakukan observasi adalah SNI 03-6572-2001 dan ASHRAE.

- Sejuk nyaman, antara temperatur efektif $20,5^{\circ} \mathrm{C}-22,8^{\circ} \mathrm{C}$.

- Nyaman optimal, antara temperatur efekt if $22,8^{\circ} \mathrm{C}-25,8^{\circ} \mathrm{C}$.

- Hangat nyaman, antara temperatur efekt if $25,8^{\circ} \mathrm{C}-27,1^{\circ} \mathrm{C}$.

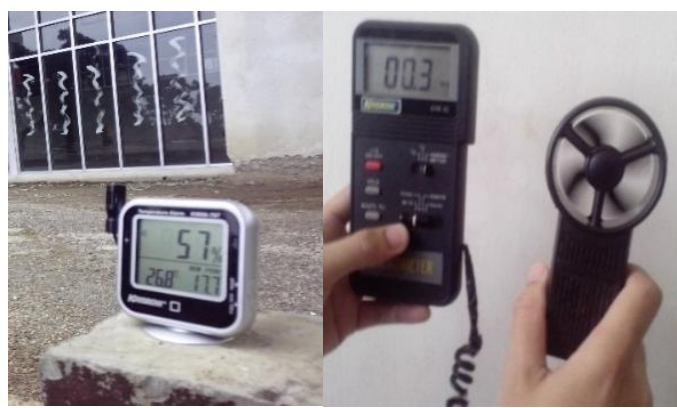

Gambar 5. Pengukuran suhu dan kecepatan angin ruangan

Berdasarkan hasil observasi dan evaluasi yang dilakukan, didapatkan informasi sebagai berikut:

- Secara keseluruhan, temperatur dalam gedung telah memenuhi syarat pada musim hujan $\left(22,8-27,1^{\circ} \mathrm{C}\right)$ namun belum memenuhi syarat pada musim panas $(22,8$ $\left.25,8^{\circ} \mathrm{C}\right)$.

- Laju udara pada lantai 1 adalah yang terendah dibandingkan dengan lantai yang lainnya. Diketahui pula bahwa jendela pada lantai satu bersifat permanen(tidak bisa dibuka) sehingga dapat menghambat aliran udara ala mi.

\section{Evaluasi Sistem Pengkondisian Udara Mekanis}

Untuk mengevaluasi pengkondisian udara mekanis dibutuhkan perhitungan mengenai beban kalor internal (beban orang, lampu, dan peralatan) dan eksternal (beban konduksi atap, jendela, dinding, radiasi matahari, dan CLTD) yang kemudian akan dibandingkan dengan kapasitas alat pendingin yang akan digunakan.

Contoh hasil evaluasi beban pendingin mekanis dapat dilihat pada Tabel 2 perhitungan berikut: 
Tabel 2. Perhitungan Beban Total

\begin{tabular}{|c|c|c|c|c|}
\hline Lantai & \multicolumn{4}{|c|}{ Lantai 1 } \\
\hline Ruangan & \multicolumn{3}{|c|}{ Administrasi Perpustakaan } \\
\hline Jam operasional & Total & Kapasitas & Keterangan \\
\hline 7 & 3550,00 & 12000 & Lebih & 8450 \\
\hline 8 & 5640,49 & 12000 & Lebih & 6359,51 \\
\hline 9 & 6050,39 & 12000 & Lebih & 5949,61 \\
\hline 10 & 6296,33 & 12000 & Lebih & 5703,67 \\
\hline 11 & 6501,28 & 12000 & Lebih & 5498,72 \\
\hline 12 & 6665,24 & 12000 & Lebih & 5334,76 \\
\hline 13 & 6829,2 & 12000 & Lebih & 5170,8 \\
\hline 14 & 6911,18 & 12000 & Lebih & 5088,82 \\
\hline 15 & 6993,16 & 12000 & Lebih & 5006,84 \\
\hline 16 & 5107,62 & 12000 & Lebih & 6892,38 \\
\hline 17 & & & & \\
\hline 18 & & & & \\
\hline 19 & & & & \\
\hline 20 & & & & \\
\hline 21 & & & & \\
\hline
\end{tabular}

Berdasarkan tabel tersebut dapat diketahui bahwa beban kapasitas AC yang direncanakan ternyata masih terlalu besar dari hasil perhitungan total. Hal ini dapat menimbulkan pemborosan energi sehingga diusulkan untuk menggunakan spesifikasi AC yang lebih rendah.

\section{Perencanaan Ulang Sistem Pencahayaan dan Pengkondisian Udara}

Sesuai dengan hasil observasi dan evaluasi yang telah dilakukan, dapat diketahui bahwa masih terdapat beberapa kekurangan pada sistem pencahayaan dan pengkondisian udarapada gedung kondisi eksisting. Untuk itu diperlukan perencanaan ulang pada kedua sistem tersebut. Perencanaan ulang dilakukan dengan tujuan mengupayakan perbaikan berdasarkan hasil data evaluasi pengujian dengan tujuan untuk mengefektifkan kerja suatu sistem tersebut tanpa harus mengurangi kualitasnya. Berikut merupakan alternatif perencanaan ulang yang diusulkan:

Sistem Pencahayaan

- Pe masangan glassblock

- Penggantian spesifikasi dan jen is lampu

- Penggunaan cerobong cahaya

- Penggantian warna cat dinding interior

Sistem Pengkondisian Udara

- Desain ventilasi Alami (cross ventilation)

- Penggunaan Exhaust Fan

- Penggantian jenis dan spesifikasi AC

\section{Pemasangan Glassblock}

Berdasarkan hasil pengukuran intensitas pencahayaan alami, diketahui bahwa pencahayaan yang paling dekat dengan bukaan terbesar (TUU1) relatif mempunyai intensitas pencahayaan yang baik(telah sesuai standar), sedangkan untuk TUU2 dan TUU3 yang mempunyai jarak 5 meter dan 7 meter dari bukaan memiliki intensitas pencahayaan yang kurang dari standar. Oleh karena itu, perlu dilakukan pemantulan/ refleksi cahaya yang masuk dari arah bukaan. Bidang pemantul yang dapat digunakan adalah berupa material glassblock.

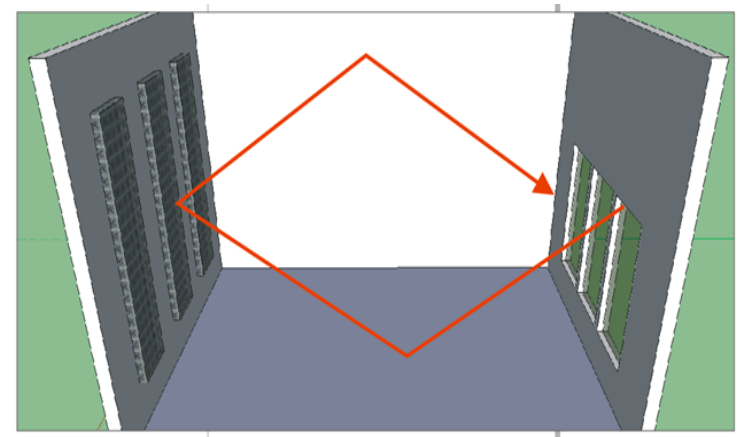

Gambar 6. Skema pemantulan cahaya menggunakan glassblock

\section{Penggantian Jenis dan Spesifikasi Lampu}

Untuk memenuhi kebutuhan pencahayaan pada gedung MST, dilakukan pergantian jenis dan spesifikasi lampu yang lebih hemat energi untuk menghindari pemboros an energi lis trik.

Adapun beberapa lampu yang diusulkan adalah sebagai berikut:

Tabel 3. Jen is la mpu yang diusulkan

\begin{tabular}{|c|c|}
\hline Eksisting & Redisain \\
\hline TL 2x36 W & LED 2x18 W \\
\hline Downlight PLC $13 \mathrm{~W}$ & Downlight 25 W \\
\hline TL 36 W & LEDT8 22 W \\
\hline TL $18 \mathrm{~W}$ & Tube 9 W \\
\hline PL 5x26 W & Hiled Light 30 W \\
\hline
\end{tabular}

1. Untuk ruangan kelas, Administrasi dan Ruang Staff

Hiled LED 2X18W, nilai lu minensi 2800

2. Untuk Ruang Perpustakaan dan ruang Expo hasil penelitian

Hiled LED 2X18W, nilai lu minensi 2800

3. Untuk Lobby

Hiled Downlight 25W, nilai luminensi 1800

4. Untuk Toilet

Hiled LED T8 LED 22W, nilai luminensi 2100

5. Untuk Ruangan kontrol panel dan gudang Hiled Tube 9W, nilai lu minensi 900

6. Untuk ruang rapat Hiled Light 30W, nilai lu minensi 2700

\section{Desain Cerobong Cahaya}

Desain cerobong cahaya bertujuan untuk:

- Untuk memaksimalkan asupan sinar matahari langsung secara terpusat pada ruangan tertentu

- Mengurangi ketergantungan penggunaan lampu di siang hari 
- Menyediakan media pencahayaan alami tanpa harus merubah struktur
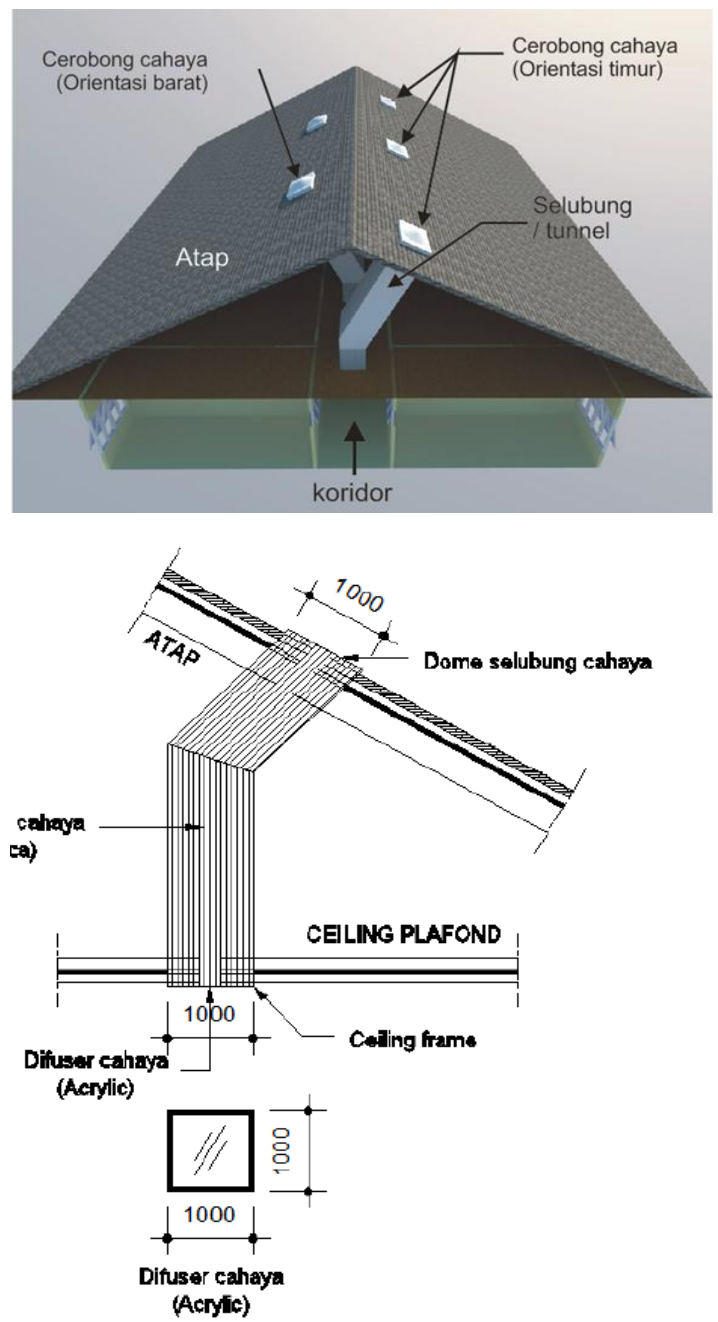

Gambar 7. Desain cerobong cahaya yang diusulkan

\section{Penggantian Warna Cat Dinding}

Berdasarkan kondisi eksisting Gedung, warna cat yang direncanakan yaitu warna putih gading dengan nilai faktor refleksi yaitu 70 - 80. Untuk memaksimalkan penerangan pada ruangan, dapat dilakukan penggantian warna cat rencana dengan warna baru yaitu warna putih dengan nilai faktor refleksi yaitu 80 - 85. Sehingga didapat kenaikan persentase pencahayaan akibat penggantian warna mencapai $21 \%$.



Gambar 8. Faktor refleksi penggantian warna cat dinding

\section{Perencanaan Ventilasi Alami}

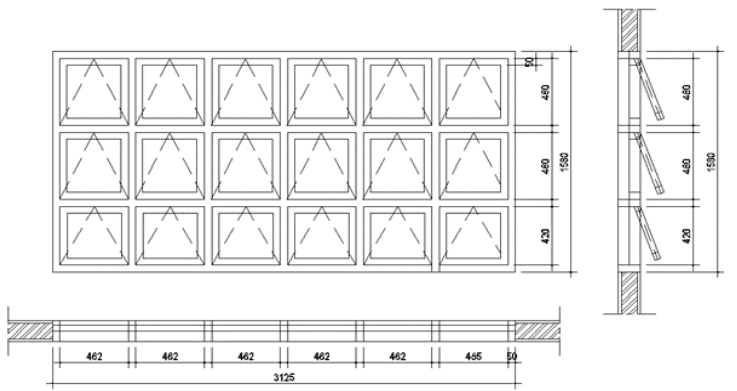

Gambar 9. Jendela Usulan Desain

Pemasangan jendela interior sebagai ventilasi alami bertujuan untuk memaksimalkan cross ventilation pada lantai 1 sampai lantai 5. Jendela dapat dibuka tutup sehingga dapat dipakai sesuai kebutuhan.

\section{Penggunaan Exhaust Fan}

Prinsip kerja exhaust fan adalah menyedot udara didalam ruangan sehingga udara segar dari luar ruangan mengalir kedalam ruangan tersebut. Penggunaan exhaust fan juga memiliki kelebihan lain yaitu usia aset yang lebih lama dan harga exhaust fan lebih murah daripada AC. Exhaust fan yang direkomendasikan adalah tipe ventilating fan yang dilengkapi dengan pipa penyalur udara keluar (ducting).

Spesifikasi Exhaust Fan yang digunakan adalah sebagai berikut:

- Exhaust Fan $430 \mathrm{CMH}, 77 \mathrm{~W}$ att

- Exhaust Fan $530 \mathrm{CMH}, 90 \mathrm{Watt}$

- Exhaust Fan $640 \mathrm{CMH}, 122 \mathrm{Watt}$ 


\section{Penggantian Jenis dan Spesifikasi AC}

Penggantian spesifikasi AC yang digunakan agar lebih menghemat penggunaan beban listrik. AC yang diusulkan bervariatif, mulai dari 0,5 PK sampai dengan $3 \mathrm{PK}$.

Berikut adalah penggantian AC yang diusulkan:

Tabel 4. Jen is AC yang diusulkan

\begin{tabular}{|c|c|}
\hline Eksisting & Redesign \\
\hline $\begin{array}{c}\text { AC Split 1,25 PK, } \\
\text { Kapasitas 12000 Btu/hr }\end{array}$ & AC Split 12000 Btu/h, 1,5 PK \\
\hline $\begin{array}{c}\text { AC Cassette 5 PK, } \\
\text { Kapasitas 45000 Btu/hr }\end{array}$ & AC Split $18000 \mathrm{Btu} / \mathrm{h}, 2 \mathrm{PK}$ \\
\hline $\begin{array}{c}\text { AC Cassette 1,25 PK, } \\
\text { Kapasitas 12000 Btu/hr }\end{array}$ & AC Split $8500 \mathrm{Btu} / \mathrm{h}, 1 \mathrm{PK}$ \\
\cline { 2 - 2 } & AC Split 25000 Btu/h, 3 PK \\
\hline
\end{tabular}

\section{Biaya Operasional Gedung Hasil Desain Ulang}

Biaya operasional yang dihitung adalah biaya pemakaian konsumsi listrik sistem pencahayaan dan pengkondisian udara pada Gedung MST. Berikut adalah perbandingan hasil perhitungan biaya operasional gedung eksisting dan hasil redisain:

Tabel 5. Biaya total hasil desain ulang

\begin{tabular}{|c|c|c|c|}
\hline \multicolumn{4}{|c|}{ Perbandingan biaya lampu } \\
\hline \multirow{2}{*}{ Kondisi eksisting } & & bulan & Biaya per tahun \\
\hline & $\mathrm{Rp}$ & 8.781 .323 & Rp 105.375 .871 \\
\hline \multirow{2}{*}{ Kondisi redesain } & & bulan & Biaya per tahun \\
\hline & $\mathrm{Rp}$ & 4.674 .661 & Rp $\quad 56.095 .928$ \\
\hline
\end{tabular}

\begin{tabular}{|c|c|c|c|}
\hline \multicolumn{4}{|c|}{ Perbandingan biaya pengkondisian udara } \\
\hline \multirow{2}{*}{ Kondisi eksisting } & & er bulan & Biaya per tahun \\
\hline & $\mathrm{Rp}$ & 44.411 .846 & $\begin{array}{ll}\text { Rp } & 347.792 .697\end{array}$ \\
\hline \multirow{2}{*}{$\begin{array}{l}\text { Kondisi redesain } \\
(\mathrm{AC}+\mathrm{EF})\end{array}$} & \multicolumn{2}{|c|}{ Biaya per bulan } & Biaya per tahun \\
\hline & $\mathrm{Rp}$ & 6.657 .448 & Rp $\quad 54.644 .796$ \\
\hline
\end{tabular}

\begin{tabular}{|c|cc|c|}
\hline \multicolumn{3}{|c|}{ Perbandingan biaya total (lampu + pengkondisian udara) } \\
\hline \multirow{2}{*}{ Kondisi eksisting } & \multicolumn{2}{|c|}{ Biaya per bulan } & \multicolumn{1}{c|}{ Biaya per tahun } \\
\cline { 2 - 4 } & $\mathrm{Rp}$ & 53.193 .169 & $\mathrm{Rp} 453.168 .568$ \\
\hline \multirow{2}{*}{ Kondisi redesain } & \multicolumn{2}{|c|}{ Biaya per bulan } & \multicolumn{2}{c|}{ Biaya per tahun } \\
\cline { 2 - 4 } & $\mathrm{Rp}$ & 11.332 .109 & $\mathrm{Rp} 110.740 .724$ \\
\hline
\end{tabular}

Berikut pada Tabel 6 adalah total perhitungan biaya secara keseluruhan meliputi biaya perawatan, penggantian komponen, depresiasi, dan persentase kenaikan biaya lis trik rata-rata:
Tabel 6. Total biaya operasional (dita mbah biaya penggantian, perawatan, dan kenaikan tarif listrik) kondisi eksisting

\begin{tabular}{|c|c|c|c|c|c|}
\hline \multirow{2}{*}{ Tahum } & \multirow{2}{*}{$\begin{array}{l}\text { Persentase kenaikan } \\
\text { listrik rata2/ thhm }\end{array}$} & \multicolumn{4}{|c|}{ Eksisting (Rp) } \\
\hline & & Bixya Operasional & Replacement & Maintenance & Total (FV) \\
\hline 2015 & $19 \%$ & $\begin{array}{ll}R p & 453.168 .568\end{array}$ & $\mathrm{Rp}$ & $\begin{array}{ll}\mathrm{Rp} & 31.134 .081\end{array}$ & 484.302 .649 \\
\hline 2016 & $19 \%$ & $\begin{array}{ll}\text { Rp } \quad 539.270 .596 \\
\end{array}$ & $R p$ & $\begin{array}{ll}\operatorname{Rp} \quad 33.469 .137 \\
\end{array}$ & 572.739 .733 \\
\hline 2017 & $19 \%$ & Rp $\quad 641.732 .009$ & $R p$ & $\begin{array}{ll}\mathrm{Rp} & 35.979 .322 \\
\end{array}$ & 677.711 .331 \\
\hline 2018 & $19 \%$ & $\begin{array}{ll}R p & 763.661 .091\end{array}$ & $R p$ & Rp $\quad 38.677 .771$ & 802.338 .862 \\
\hline 2019 & $19 \%$ & $\begin{array}{ll}R p & 908.756 .698\end{array}$ & $\begin{array}{ll}\mathrm{Rp} & 659.129 .000\end{array}$ & $\begin{array}{ll}\mathrm{Rp} & 41.578 .604\end{array}$ & $\operatorname{Rp} \quad 1.609 .464 .302$ \\
\hline 2020 & $19 \%$ & Rp 1.081.420.471 & $R p$ & Rp $\quad 44.696 .999$ & $\begin{array}{ll}R p & 1.126 .1177 .470\end{array}$ \\
\hline 2021 & $19 \%$ & Rp 1.286 .890 .360 & $R p$ & $\operatorname{Rp} \quad 48.049 .274$ & $\begin{array}{ll}\operatorname{Rp} & 1.334 .939 .635 \\
\end{array}$ \\
\hline 2022 & $19 \%$ & Rp 1.531.399.529 & $\mathrm{Rp}$ & $\begin{array}{ll}\mathrm{Rp} & 51.652 .970\end{array}$ & $\begin{array}{ll}R p & 1.583 .052 .499\end{array}$ \\
\hline 2023 & $19 \%$ & Rp 1.822 .365 .439 & $\mathrm{Rp}$ & $\begin{array}{ll}\text { Rpp } & 55.526 .942 \\
\end{array}$ & $\begin{array}{ll}R_{p} & 1.877 .892 .382\end{array}$ \\
\hline 2024 & $19 \%$ & Rp 2.168.614.873 & Rp 1.1 .173 .029 .000 & $\begin{array}{ll}\mathrm{Rp} & 59.691 .463\end{array}$ & Rp $\quad 3.401 .335 .336$ \\
\hline 2025 & $19 \%$ & Rp 2.580 .651 .699 & $R p$ & $\begin{array}{ll}\text { Rp } \quad 64.168 .323 \\
\end{array}$ & $\begin{array}{ll}\text { Rp } \quad 2.644 .820 .022 \\
\end{array}$ \\
\hline 2026 & $19 \%$ & Rp 3.070 .975 .522 & $R p$ & Rp $\quad 68.980 .947$ & $\begin{array}{ll}\text { Rp } & 3.139 .956 .469\end{array}$ \\
\hline 2027 & $19 \%$ & $\operatorname{Rp} 3.654 .460 .871$ & Rp & Rp $\quad 74.154 .518$ & $\begin{array}{ll}\text { Rp } \quad 3.728 .615 .389\end{array}$ \\
\hline 2028 & $19 \%$ & Rp 4.348.808.436 & $R p$ & $\begin{array}{ll}\mathrm{Rp} & 79.716 .107\end{array}$ & Rp $\quad 4.428 .524 .543$ \\
\hline 2029 & $19 \%$ & Rp 5.175 .082 .039 & $\begin{array}{ll}\mathrm{Rp} & 659.129 .000 \\
\end{array}$ & Rp $\quad 85.694 .815$ & $R_{p} \quad 5.919 .905 .854$ \\
\hline 2030 & $19 \%$ & $R p \quad 6.158 .347 .626$ & $R p$ & Rp $\quad 92.121 .926$ & Rp $\quad 6.250 .469 .553$ \\
\hline 2031 & $19 \%$ & $\operatorname{Rp} 7.328 .433 .675$ & Rp & 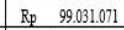 & $\begin{array}{ll}\mathrm{Rp} & 7.427 .464 .746\end{array}$ \\
\hline 2032 & $19 \%$ & Rp 8.720 .836 .074 & $R p$ & $\begin{array}{ll}R p & 106.458 .401\end{array}$ & $\begin{array}{ll}R_{p} & 8.827 .294 .475\end{array}$ \\
\hline 2033 & $19 \%$ & $\operatorname{Rp} 10.377 .794 .928$ & $\mathbb{R p}$ & Rp 114.442 .781 & $\begin{array}{ll}\text { Rp } \quad 10.492 .237 .709\end{array}$ \\
\hline 2034 & $19 \%$ & $\operatorname{Rp} 12.349 .575 .964$ & $\operatorname{Rp} 1.173 .029 .000$ & Rp $\quad 123.025 .990$ & $\operatorname{Rp} \quad 13.645 .630 .954$ \\
\hline 2035 & $19 \%$ & Rp 14.695.995.397 & $\mathrm{Rp}$ & $\begin{array}{lll}\text { Rp } \quad 132.252 .939\end{array}$ & $\begin{array}{ll}\text { Rp } & 14.828 .248 .336\end{array}$ \\
\hline \multicolumn{5}{|c|}{ Total (FV) } & Rp 94.803 .062 .248 \\
\hline \multicolumn{5}{|c|}{ Nilas sila a get } & Rp $\quad 1.299 .485 .000$ \\
\hline \multicolumn{5}{|c|}{ Total - Nilai sisa aset } & Rp 93.503 .577 .248 \\
\hline & & Total (dalam L & & & $\begin{array}{lll}\text { Rp } & 21.646 .619 .142\end{array}$ \\
\hline
\end{tabular}

Berdasarkan tabel diatas diketahui biaya total yang terdiri dari biaya operasional, penggantian aset, dan pemeliharaan aset tersebutpada kondisi eksisting yaitu Rp. 21.646.619.142 (dalam present value). Nilai tersebut merupakan biaya yang akan dikeluarkan selama 20 tahun mendatang, terhitung mulai tahun 2015 sampai dengan 2035. Diketahui kenaikan tingkat inflasi rata - rata per tahun yaitu 7,59\% (Sumber Badan Pusat Statistik tahun 2015).

Tabel 7. Total biaya operasional (dita mbah biaya penggantian, perawatan, dan kenaikan tarif listrik) setelah desain ulang

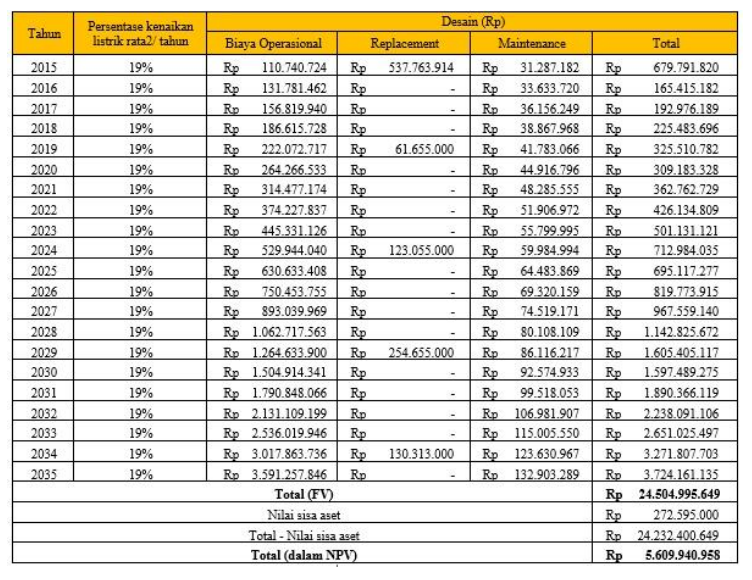

Berdasarkan tabel diatas diketahui biaya total selama 20 tahun yang terdiri dari biaya operasional, penggantian aset, dan pemeliharaan aset setelah adanya desain ulang yaitu Rp. 5.609.940.958 (dalam present value). 
Dengan demikian, berdasarkan pada Tabel 6 dan Tabel 7 di atas, ditunjukkan bahwa dari segi biaya operasional keseluruhan, kondisi gedung setelah dilakukan desain ulang memiliki nilai yang lebih kecil bila dibandingkan biaya operasional dalam kondisi eksisting. Nilai optimalisasi dan penghematan dari desain baru mencapai $286 \%$ per tahun dari nilai cash flow aset (replacement dan maintenance).

Grafik di bawah ini menunjukan perbandingan nilai cash flow selama 20 tahun kedepan terkait biaya operasional, pemeliharaan, perbaikan, pergantian aset, dan biaya investasi (hanya pada usulan desain) dengan nilai inflasi berdasarkan data dari Badan Pusat Statistik tahun 2015.



Gambar 10. Grafik perbandingan cash flow kondisi eksisting dan redisain

Berdasarkan grafik di atas, dapat diketahui jika perbandingan nilai cash flow selama 20 tahun kedepan untuk hasil redisain lebih hemat. Namun pada tahun pertama, kondisi redisain memiliki nilai yang lebih besar. Nilai tersebut dipengaruhi oleh nilai investasi atau RAB yang diusulkan.

\section{Rencana Anggar an Biaya (RAB)}

Rencana Anggaran Biaya yang diperhitungkan hanya berfokus pada sistem pencahayaan dan pengkondisian udara pada Gedung MST Polban. Berikut adalah RAB yang diusulkan sesuai hasil desain ulang:

Tabel 8. RAB pekerjaan hasil redesain

\begin{tabular}{|c|c|c|c|c|c|c|c|}
\hline$N_{0}$ & Item & Satuan & Jumlah & \multicolumn{2}{|c|}{ Harga } & \multicolumn{2}{|r|}{ Total } \\
\hline $\mathrm{A}$ & PEKERJAAN & & & & & & \\
\hline 1 & Pembongkaran plesteran dinding & $\mathrm{m} 2$ & 249,88 & $R p$ & 4.875 & $R p$ & 1.218 .165 \\
\hline 2 & Pembongkaran kaca jendela interior & $\mathrm{m} 2$ & 551,92 & $\mathrm{Rp}$ & 5.205 & $\mathrm{Rp}$ & 2.872 .74 \\
\hline 3 & Pembongkaran plafond dan ceiling & $\mathrm{m} 2$ & 86,5 & $R p$ & 6.955 & $R p$ & 601.608 \\
\hline 4 & Pembongkaran instalasi label listrik & $\mathrm{m}$ & 50 & Rp & 8.300 & Rp & 415.000 \\
\hline 5 & Pembongkaran atap untuk cerobong cahaya & bh & 42,68 & $R p$ & 88.067 & Rp & 3.758 .700 \\
\hline 6 & Pembongkaran insulassi atap & $\mathrm{m} 2$ & 42,68 & $\mathrm{Rp}$ & 9.437 & Rpp & 402.771 \\
\hline 7 & Pemaxangan glassblock & $\mathrm{m} 2$ & 249,88 & $R p$ & 30.340 & $R p$ & 7.581 .359 \\
\hline 8 & pemasangan jendela hidup (interior) & $\mathrm{m} 2$ & 124,44 & $\mathrm{Rp}$ & 24.995 & $\mathrm{Rp}$ & 3.110 .378 \\
\hline 9 & pemasangan instalasi $A C$ & bh & 17 & $R p$ & 57.000 & $R p$ & 969.000 \\
\hline 10 & Pemasangan instalasi Exhaust Fan + ducting & bh & 34 & Rpp & 356.000 & $R p$ & 12.104 .000 \\
\hline 11 & Pengecatan ulang ( dinding interior) & $\mathrm{m} 2$ & 249,88 & $\mathrm{Rp}$ & 39.000 & Rp & 9.745 .320 \\
\hline 12 & Pemasangan kembali insulasi atapp & $\mathrm{m} 2$ & 42,68 & $\mathrm{Rp}$ & 12.500 & Rp & 533.500 \\
\hline 13 & Pengecatan plafond & $\mathrm{m} 2$ & 86,5 & $R p$ & 4.340 & $R p$ & 375.410 \\
\hline
\end{tabular}

Tabel 9. RAB kebutuhan bahan

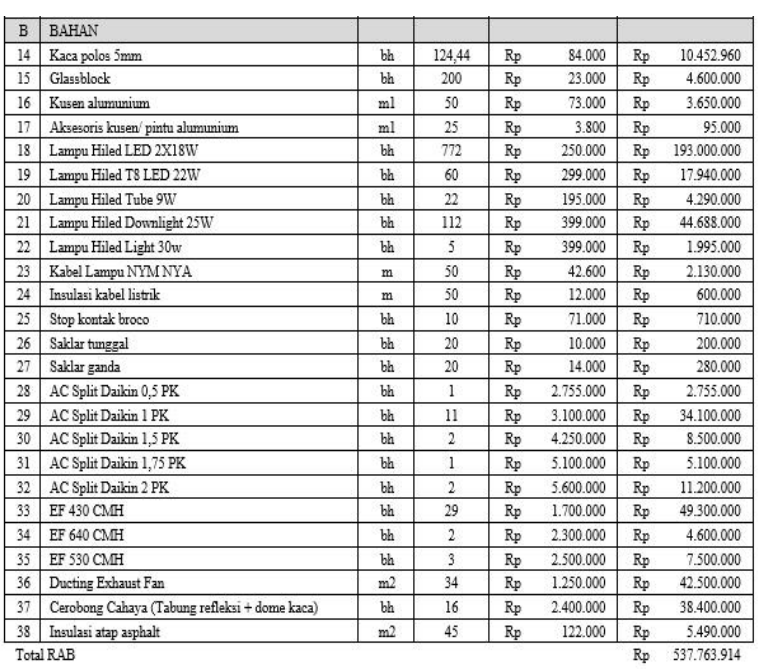

Berdasarkan Rencana Anggaran Biaya yang telah diusulkan, dapat diketahui bila biaya investasi yang diusukan pada tahun pertama adalah sebesar Rp. 537.763.914.

\section{KESIMPULAN}

Berdasarkan hasil evaluasi dan analisis sistem pencahayaan dan pengkondisian udara yang telah dilakukan, didapatkan beberapa poin sebagai berikut:

1. Intensitas pencahayaan alami yang kurang terdapat pada jam operasional pagi, sedangkan pada siang hari dan sore hari mempunyai intensitas pencahayaan yang paling tinggi.

2. Titik ukur terjauh dari bukaan mempunyai intensitas pencahayaan alami yang kurang.

3. Pada pencahayaan buatan, diketahui bahwa pada lantai 1 untuk beberapa ruangan mempunyai intensitas pencahayaan yang kurang, dengan selisih berkisar antara 10\% $77 \%$ dari standar pencahayahaan masing masing ruangan. Sedangkan untuk lantai 2 sampai lantai 5 , intensitas pencahayaan buatan yang didapatkan relatif berbeda.

4. Pada sistem pengkondisian udara alami, diketahui bahwa pada seluruh ruangan cenderung masuk dalam kategori Nyaman optimal dengan suhu berkisar antara $22,8^{\circ} \mathrm{C}-$ $25,8^{\circ} \mathrm{C}$.

5. Pada pengkondisidan udara mekan is, terdapat beberapa ruangan yang mempunyai kapasitas terlampau jauh dari beban total yang ada. Seperti pada ruangan Perpustakaan lantai 1 yang mempunyai beban total maksimal yaitu $6993 \mathrm{btu} / \mathrm{hr}$ sedangkan kapasitas AC sebesar $12000 \mathrm{btu} / \mathrm{hr}$. Sama halnya dengan beberapa ruangan lainnya seperti ruang rapat lantai 2, ruang Applied Technology Center lantai 3, ruang staf lantai 4 dan ruang admin istrasi prodi lantai 5. 
6. Kecepatan dan laju udara lantai 1 dinilai kurang efektif, hal tersebut dikarenakan jendela eksterior yang merupakan jendela mati, sehingga asupan udara segar dari luar ruangan tidak bisa didistribusikan ke setiap interior ruangan. Sedangkan untuk lantai $2-5$ mempunyai laju dan kecepatan udara yang cukup.

Sehingga perlu dilakukan perencanaan ulang dan perubahan desain terhadap beberapa komponen sistem pencahayaan dan pengkondisian udara. Perubahan desain yang dilakukan diantaranya adalah:

1. Sistem pencahayaan

- Pemasangan glassblock pada lantai 1 sampai lantai 5 untuk meminimalisir penggunaan lampu berlebih pada jam operasional serta menambah intensitas pencahayaan pada suatu ruangan yang mempunyai area terjauh dari bukaan yang ada.

- Pemasangancerobong cahaya pada area lantai 5 (koridor). Pada kondisi eksisting, nilai biaya operasional penggunaan lampu adalah sebesar Rp. 3.291.936 per tahun, sedangkan setelah dilakukan pemasangan cerobong cahaya, kebutuhan pencahayaan area koridor pada jam operasional (07.00 17.00) telah terpenuhi. Sehingga tidak memerlukan penggunaan pencahayaan buatan/lampu.

- Perubahan spesifikasi lampu yang lebih ramah lingkungan dan mempunyai life hour yang lebih lama. Penggantian spesifikasi lampu tersebut dilakukan untuk memenuhi kebutuhan pencahayaan buatan pada setiap ruangan, serta mampu menekan biaya operasional akibat penggunaan lampu. Pada kondisi eksisting diketahui biaya operasional akibat lampu yaitu sebesar RpRp 105.375.871 per tahun, sedangkan biaya operasional hasil perencanaan ulang yaitu sebesar Rp. 56.095.928 per tahun, sehingga didapatkan persentase penghematan biaya operasional dari hasil perencanaan ulang yaitu sebesar $87,8 \%$

- Penggantian warna cat rencana (berdasarkan RKS) dengan warna cat yang lebih terang. Hal tersebut dilakukan untuk menambah nilai refleksi cahaya akibat warna cat dinding.
2. Sistem pengkondisian udara

- Penggantian jendela interior dari jendela mati ke jendela hidup. Jendela hidup tersebut berfungsi sebagai penambahan laju aliran udara alami dari luar ke setiap ruangan gedung dengan menerapkan metode cross ventilation.

- Penggantian spesifikasi AC yang bertujuan untuk menghemat penggunaan beban listrik berlebih akibat penggunaan AC. AC yang diusulkan bervariatif, mulai dari 0,5 PK s/d 3 PK. Pada kondisi eksisting diketahui biaya operasional akibat penggunaan AC yaitu sebesar Rp 347.792.697 per tahun, sedangkan biaya operasional hasil perencanaan ulang yaitu sebesar Rp. 54.644.796 per tahun

- Pemasangan Exhaust Fan yang berfungsi untuk menyedot udara panas dari masing - masing ruangan, serta untuk mengurangi ketergantungan pemakaian AC. Dilakukan kombinasi AC dan Exhaust Fan pada lantai 3 dan 4 , serta di seluruh ruangan lantai 5 .

Dari hasil perhitungan telah didapatkan bahwa selisih atau nilai penghematan hasil desain dengan kondisi eksisting yaitu sebesar 286\%.Pada kondisi eksisting, total biaya keseluruhan akibat biaya operasional, biaya penggantian aset dan peme liharaan selama 20 tahun $(2015$ - 2035) yaitu sebesar Rp. 21.646.619.142 (dalam Net Present Value), sedangkan total biaya keseluruhan hasil desain yaitu Rp. 5.609.940.958. sehingga didatapkan persentase penghematan keseluruhan yaitu sebesar $286 \%$.

\section{Saran}

1. Melakukan penanaman pohon di bagian depan gedung (timur) agar aliran udara yang masuk melalui bukaan ke dalam ruangan memiliki kualitas udara yang bersih dan segar serta memberikan kenyamanan bagi penghuni gedung. Pohon yang ditanam sebisa mungkin tidak mengganggu pencahayaan akibat sinar matahari yang berorientasi dari arah timur gedung.

2. Memasang tirai jendela di setiap ruangan dengan tujuan untuk mengurangi pencahayaan langsung akibat radiasi sinar matahari serta untuk mengurangi efek silau kepada penghuni ruangan. 
3. Waktu/ lama penggunaan lampu, AC dan Exhaust fan harus disesuaikan dengan hasil evaluasi dan perencanaan, sehingga diharapkan dapat mengurangi biaya operasional akibat penggunaan listrik berlebih.

4. Berdasarkan hasil analisis dan perencanaan yang telah dilakukan, diharapkan agar pihak manajemen/ Instansi terkait menerapkan hasil perencanaan ulang yang diusulkan sehingga dapat mengurangi ketergantungan akibat listrik berlebih yang berpengaruh terhadap pengeluaran biaya operasional pada Gedung MST POLBAN.

\section{Daftar Pustaka}

Departemen Pekerjaan Umum. 2014. "Daftar Harga Material dan Analisis Harga Satuan Pekerjaan kota Bandung, Provinsi Jawa Barat". Bandung

Faizal, Diki. 2013 "Identifikasi Pencahayaan Dan Tata Udara Gedung Elemen Politeknik Negeri Bandung”. Politkentik Negeri Bandung

McGu inness, Stein, Reynolds. 1980. "Mechanical and Electrical Equipment for Building”. New York

Pusat Informasi Pengembangan Permukiman dan Bangunan (PIP2B). "Draft Pedoman Umum Perencanaan Bangunan Gedung”

Standar Nasional Indonesia (SNI 6197-2011). "Konversi Energi Pada Sistem Pencahayaan Bangunan

Standar Nasional Indonesia (SNI 6390-2011). "Konversi Energi Pada Sistem Tata Udara Bangunan Gedung

Standar Nasional Indonesia (SNI 16-7062-2004). "Pengukuran Intensitas Penerangan Di Tempat Kerja”

Standar Nasional Indonesia (SNI 03-2396-2001). "Tata Cara Perancangan Sistem Pencahayaan Alami Pada Bangunan Gedung

Standar Nasional Indonesia (SNI 03-6572-2001). "Tata Cara Perancangan Sistem Ventilasi Dan Pengkondisian Udara"

Sulistya, Shona dan Muhammad Iqbal 2014. "Optimalisasi Tata Udara Dan Tata Cahaya Dengan Parameter Biaya Operasional Pada Gedung Jurusan Teknik Sipil 2 Politeknik Negeri Bandung”. Politeknik Negeri Bandung

United States Department of Housing and Urban Development. "ASHRAE GRIP 158 Cooling and Heating Load Calculation Manual" 